\title{
GIS application in abiotic risks regionalization for spring barley
}

\author{
Tomáš STŘEDA ${ }^{1,2, *}$, Radim CERKAL ${ }^{1}$, Lenka HÁJKOVÁ ${ }^{2}$, \\ Filip CHUCHMA ${ }^{1,2}$, Tomáš KHEL ${ }^{3}$, Jana KLIMEŠOVÁ ${ }^{1}$ \\ ${ }^{1}$ Mendel University in Brno, \\ Zemědělská 1665/1, 61300 Brno, Czech Republic \\ ${ }^{2}$ Czech Hydrometeorological Institute, \\ Na Šabatce 2050/17, 14306 Praha - Komořany, Czech Republic \\ ${ }^{3}$ Research Institute for Soil and Water Conservation, \\ Žabovřeská 250, 15627 Praha - Zbraslav, Czech Republic
}

\begin{abstract}
In recent years, there has been a noticeable uneven distribution of rainfall in Central Europe during the main vegetation season of most field crops. The rising air temperatures also increase the evapotranspiration demands of the environment and increase the frequency and length of heatwaves, which is a stress factor for plants. Using the GIS procedures, we identified the areas of significant abiotic risks occurring during the critical growth stages of spring barley (high air temperatures at the time of tillering and lack of soil moisture from the beginning of flowering to yellow ripening) with potential impact on grain yield in the Czech Republic. Unique datasets, including i) meteorological data, ii) phenological data, iii) pedological data, iv) land-use data, and v) geographic data, have been integrated and analysed using the sophisticated ArcGIS software environment. The method used in this study is universally applicable and allows comparisons at the local, regional, and supra-regional levels. The identification of risk areas will allow for a) finding tolerant varieties from problematic areas, b) locating the use of these varieties in risk areas and c) recommending and implementing adequate farming practices to reduce the impact of risk abiotic stressors on spring barley under current climate conditions. This will allow accurate estimation of weather impacts on spring barley grain yield in a particular year and precise application of countermeasures leading to reduced negative impacts on yield and the quality of spring barley production. Using the data and methods presented, we identified areas that correspond in good accordance to areas with spring barley yield deficits in dry years.
\end{abstract}

Key words: evapotranspiration, soil moisture, air temperature, phenology, ALADIN, barley, agroclimatology

\footnotetext{
*corresponding author: e-mail: streda@mendelu.cz
} 


\section{Introduction}

The main abiotic stressors for agricultural crops reducing yields in Europe are agricultural drought as well as high air temperatures during the main growing season. Although drought in Central Europe is a relatively recent problem, worldwide it is the most serious abiotic stress affecting crop yields in the long term (Boyer, 1982). Plant production is based on maintaining transpiration in the absence of water. All other criteria are always secondary, where biomass production is concerned (Blum, 2011; Chaves et al., 2011).

According to Bodner et al. (2015), three main types of climate can be distinguished in areas with intensive agricultural production. They differ mainly in the distribution of precipitation and evapotranspiration requirements, the type of soil and the length and beginning of the growing season. The climate of Central Europe is predominantly "supply-driven", whereby the water is mostly supplied by precipitation during the growing season. In Central Europe, there has generally been an increase in the uneven distribution of precipitation, combined with an increase in air temperature in recent decades. Although an increased incidence of extreme rainfall has been observed, local or regional drought has been more prevalent in recent decades as demands for evapotranspiration are increasing due to increasing air temperature (ك̌kvarenina et al., 2009). Analyses of precipitation characteristics in the Czech Republic show that there is no decrease in the total amount of precipitation, but rather a shift towards greater inequality of its distribution over time (during the year). In the Czech Republic's environmental conditions, the number of days without rainfall may increase from the current 79.9 days to 141.6 days from 2071 through 2100 , but no significant decrease in the amount of rainfall per year is expected. The climate models also predict an increase in the average sum of active temperatures above $10^{\circ} \mathrm{C}$ for the Czech Republic from the current $2717^{\circ} \mathrm{C}$ to $3732^{\circ} \mathrm{C}$. These changes increase the evapotranspiration demands of the environment to which agricultural crops will be exposed. In addition, temperatures above $20-25{ }^{\circ} \mathrm{C}$ can decrease the level of inhibitory substances in the plant, and thus reduce tiller formation of cereals (Rawson, 1971). The rate of tillering decreases at temperature above $25^{\circ} \mathrm{C}$ (Friend, 1966). Modern barley varieties show strong ability to make a canopy denser during tillering. Tillering is thus crucial for barley's yield creation. Having in mind that barley's yield 
is closely related to number of spikes, the low number of productive spikes might be compensated at latter phases just to a limited extent. Increasing frequency of unfavourable conditions at early spring (during tillering), especially higher temperatures and drought periods, can affect negatively the formation of spring barley yield and grain quality parameters (Křen et al., 2015), particularly under the central Europe climate. Plants grown in the warmer cropping season produced relatively few grains due to the short period of tillering as a results of high air temperatures compared with those grown in the colder crop season (Tanaka and Nakano, 2019).

The availability of soil moisture, together with global radiation and vapour pressure deficit, are among the main determinants of transpiration (Du et al., 2011; She et al., 2013; Zeppel et al., 2008). Daily or the longterm course of these variables affects the plant's transpiration flow (Naithani et al., 2012). Changes in transpiration intensity are considered to be an indicator of drought stress on the plant. Blum (2005) defines the onset of drought as a period when the plant's water demand is not satisfied, and the plant is in a water deficit. Lipiec et al. (2013) define drought as a result of water flow imbalance between evapotranspiration environmental demands and water transport in the soil-root system. The limit value for cereals such as common wheat or barley, where there is still no reduction in transpiration, is the soil moisture in the root zone at about $50-65 \%$ of the available water holding capacity of the soil (according to various authors and the growth phase of the plant). For example, Jamieson et al. (1995) found changes in the transpiration of barley plants with water content in the soil below $65 \%$ of the available water holding capacity. This finding was similar to Matejka et al. (2005) who recorded changes in the modelled evapotranspiration of the maize crop when the available water holding capacity of the soil fell below $58.2 \%$. However, for the agriculturally intensive areas of the Czech Republic up to approx. $300 \mathrm{~m}$ above sea level, the characteristic long-term values of available water holding capacity are below $45 \%$. Our previous results also show an increase in potential evapotranspiration and thus a higher susceptibility of drought in intensive agricultural areas in South and Central Moravia and Central Bohemia in the 1961-2010 period compared to the 1901-1950 average. Scenario calculations of potential evapotranspiration predict an increase in the risk of dry episodes in the Czech Republic (Středová and Středa, 2015). 
Accurate targeting of the use of the variety to a specific area of cultivation can be a successful result. For example, deep-rooting varieties may be successful in dry years on deep soils with higher groundwater levels or sufficient water supply in the soil during winter months. However, shallow topsoil profiles of stony soils will be unsuitable for these varieties. At locations where droughts occur regularly, some strategies allow agricultural crops to survive primarily from water supplies in the soil acquired during the winter months. The occurrence of terminal drought (at the end of the growing season) is a regular phenomenon in Australia, the US and the Mediterranean. The solution may be the early varieties.

\section{Material and methods}

The resulting map was created based on the analysis of two raster inputs. The first data input was a layer of an average number of days with a maximum daily air temperature exceeding $25^{\circ} \mathrm{C}$ in the period since the beginning of the phenophase of spring barley tillering which according to the Czech Hydrometeorological Institute (CHMI) phenological database, occurs at the site plus fifteen days from the start date. The input data for the calculation consisted of the maximum daily air temperature data for a set of technical stations (a total of 268 stations within the Czech Republic). For each station, the average date of spring barley tillering was determined from the phenological layer (for the period between 1991 to 2010 the longest comprehensive range of observations available in the Czech Republic; while we are fully aware that the period does not correspond to the period of undermentioned climatological datasets. Since the phenological observation of the CHMI were officially finished in 2010 we were facing to two, both imperfect, possible approaches in terms of length of period: either to employ the parallel phenological and climatological period 2000-2010 i.e. only 11 years, or the longest possible period i.e. for temperature and evapotranspiration from 2000-2018 and 1991-2010 for phenology i.e. around 20 years) of the beginning of spring barley tillering, and the 15-day calculation period from that date was determined. For this, for each station-specific period, the number of days with a maximum daily air temperature exceeding $25^{\circ} \mathrm{C}$ was calculated for each year and station and the average annual number of days for the period 2000-2018 was calculated. These calculations resulted 
in the set of 268 technical stations with an average number of days with a maximum daily air temperature exceeding $25^{\circ} \mathrm{C}$ in the given phenological period for the period 2000-2018. A raster layer was created from this file using spatial statistics methods by interpolation into the Czech Republic area. The resulting raster model was subsequently processed in the ArcGIS 10.5 software, and the nearest neighbours smoothing method was applied. The raster layer was then reclassified into individual categories in a 0.5-day step, i.e. six categories ranging from $<1$ to $>3.1$ (Fig. 1). It is highly probable that in the areas with higher number of days with daily maximum above $25^{\circ} \mathrm{C}$ also includes temperatures catching up this threshold value. Even these higher temperatures inhibit the tillering though. Linear distribution was based on the experience that relationship between air temperature and lasting at tillering phase is linear (unless the lethal temperature is reached or exceeded).

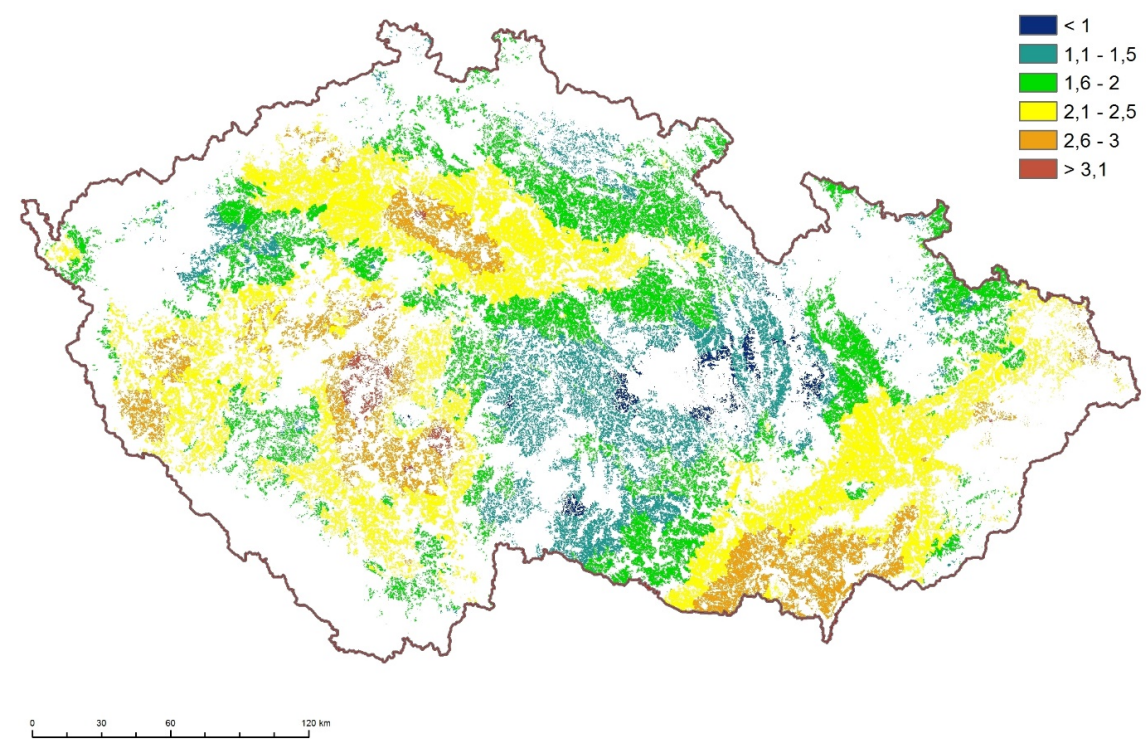

Fig. 1. Layer of the average number of days with a maximum daily air temperature exceeding $25^{\circ} \mathrm{C}$ in the period since the onset of spring barley tillering phase, plus fifteen days from this start date.

The second data input was the layer of ratio of the actual evapotranspiration sum (ETa, evapotranspiration affected by the amount of water in soil) and potential evapotranspiration sum (ETp, high environmental evap- 
oration and transpiration requirements) processed for the period 2000-2018 during the critical growth period of the spring barley from the beginning of the flowering phenophase to yellow ripening, which occurs at the site according to the CHMI phenological database (for the period 1991-2010; the longest available comprehensive series of observations in the Czech Republic). Input data ETa and ETp were calculated using the AVISO agrometeorological model (Kohut et al., 2009) from the input series of meteorological elements for stations of the CHMI station network with available measurements in the period 2000-2018. Both ETa and ETp values were calculated for spring barley. Moreover, to improve the correctness of the water abstraction intensity by evapotranspiration, for each calculation point (station), we used a specific hydro limit derived according to the available water holding capacity of soil (source: Research Institute for Soil and Water Conservation). It implicates that available water holding capacity is an integral part of the ETa parameter making our model unique, taking into account real soil conditions. Real moisture conditions in the soil profile in terms of soil parameters and evapotranspiration are reflected.

From the phenological layers, the average date of the beginning of flowering and the average date of the beginning of yellow ripening was determined for each station and a computational period was set between these dates. For this, for each station-specific period, sums ETa and ETp were calculated in individual years for the period 2000-2018. These values were then put into the sum ETa/sum ETp ratio, which is a standard index for agronomic drought identification. The resulting set of stations with the assigned value of ETa/ETp ratio in the individual years for the period 2000-2018 was created. Based on spatial statistics by interpolation into the area of the Czech Republic, annual raster layers of ETa/ETp ratio were created from this set. The resulting rasters were averaged and a raster layer of average values of the ETa/ETp ratio for the period 2000-2018 was created. The resulting raster model was subsequently processed in the ArcGIS 10.5 software, and the nearest neighbour smoothing method was used. The raster layer of ratio values was then reclassified into individual categories in a step of 0.04 , i.e. six categories from 6 to 1 for the value of categories from $<0.76$ to $>0.92$ (Fig. 2), since in this particular case the linear impact on possible yield reduction is apparent. The number of categories (i.e. six) corresponds to number of drought categories (expressed as \% of available water holding 
capacity) of the CHMI, however regarding to constriction of ETa/ETp ratio there are apparent differences from simple drought evaluation used by CHMI. Our complex and wiser index though better reflects real demands and impacts of the plants.

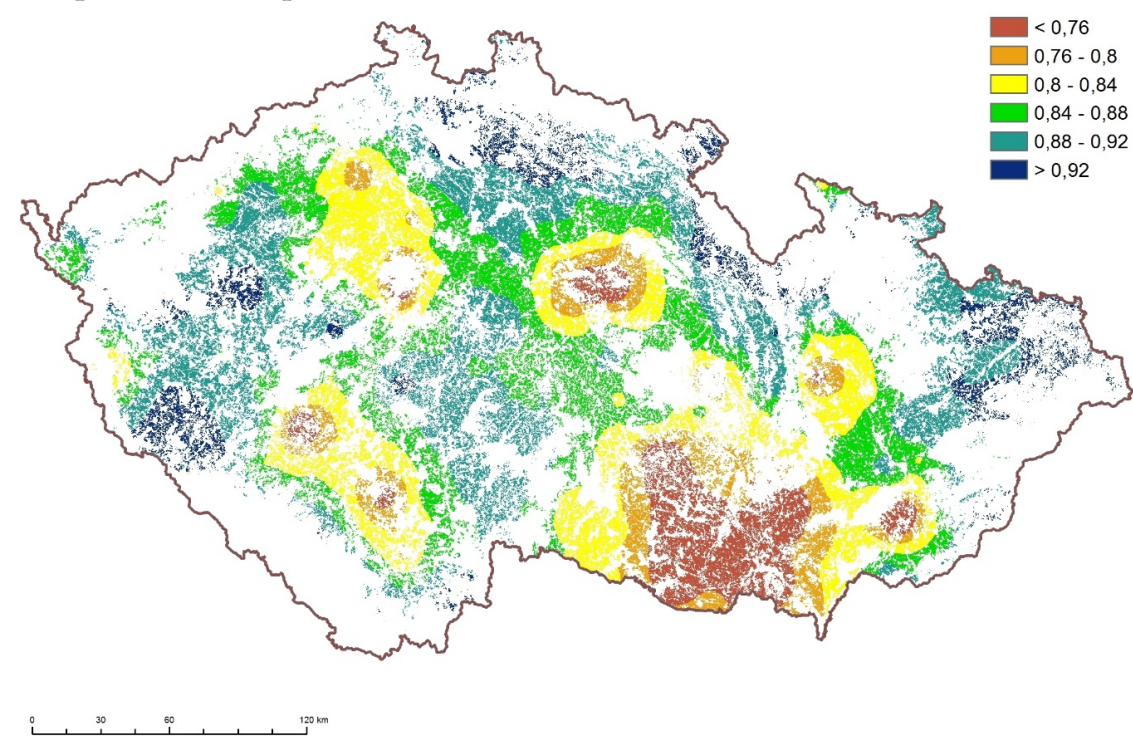

Fig. 2. Layer of the ratio of the actual evapotranspiration sum (ETa) and the potential evapotranspiration sum (ETp) for the period 2000-2018 during flowering to yellow ripening of spring barley.

Both partial raster layers (number of days category layer and ETa/ETp ratio category layer) were then summed, and the resulting sum total of the raster layer was again divided into six risk categories. The raster layer was converted to polygons and only areas under arable land (arable land layer; source: Research Institute for Soil and Water Conservation.) and at an altitude of $600 \mathrm{~m}$ above sea level (we do not expect intensive cultivation of spring malting barley at a higher altitude) were selected. The resulting map output was also created in ArcGis 10.5 software.

\section{Results and discussion}

Climate change in Europe since 1990 has been unfavourable for cereals yields because of heat stress during grain filling and drought during stem elonga- 
tion (Brisson et al., 2010). The severity of the effects of drought increases with the prolongation of its exposure during the growing season and its occurrence at critical stages of plant development. For example, flowering and the early stage of ripening are critical for cereals. The occurrence of drought during sowing and the vegetative phases of cereal growth, as well as the high temperatures at this stage, have an impact on the emergence of the crop and the consequent reduction of tillers. The effect of drought during generative phases results in a reduction in the number of spiked seeds and grains. Flowering is a critical period when water scarcity has a worse impact than at other stages of development. Another critical period is the start of grain formation, where the number of cells in the endosperm is decided. In the grain filling phase, water stress interferes with the synthesis and storage of starch and storage proteins.

In our previous work, we evaluated the moisture conditions during the vegetation period (91-180 days of the year) for the period 1975-2007 and its influence on the production of spring barley. A long-term trend of decreasing soil water supply was found in 20 out of 21 localities, expressed as $\%$ of available water holding capacity. At the same time, a statistically significant correlation was found between the yield of spring barley grain and the state of soil saturation with water, expressed in terms of the current state of $\%$ of available water holding capacity.

Mužíková et al. (2013) evaluated yields of spring barley and fluctuations in soil moisture in the critical period in terms of barley yield in the Czech Republic for the period 1975-2010. On most sites, there were statistically significant relationships between grain yield and soil moisture in different stages of vegetation. A statistically significant relationship was also found when evaluating average values of soil moisture and the average grain yield across stations. When evaluating the season-average soil moisture and yield, these researchers found a statistically significant to a highly significant year effect (1976, 1981, 1985, 1986, 1995, 1996, 2000, 2004, 2007, 2009 and 2010). In the last decade, the number of growing seasons with a demonstrable influence of moisture conditions on barley yield increased in different production areas.

Spring barley grain yields and values of the effective drought index (EDI) in the critical period in terms of yield formation of spring barley in the Czech Republic were evaluated for the period 1975-2015 (Slabá et al., 2017). In 
most areas, there were statistically significant relationships between grain yield and the EDI in different stages of vegetation (fourth and sixth decade of the vegetation primarily).

The aim of the analysis and mapping of the outcomes was to define areas with increased risk of main abiotic stressors occurrence during the critical growth and development phase of spring barley vegetation (high temperatures during tillering and drought from flowering to hard dough growth stage) in the territory of the Czech Republic (Fig. 3). Analyses were based on a sophisticated synthesis of the long-term a) meteorological datasets, b) phenological datasets, c) soil conditions data (available water holding capacity of Czech soils), d) land-use data, and e) the arable land category and maximum $600 \mathrm{~m}$ a.s.l. The current findings illustrate that $49 \%$ of the potentially usable areas of spring barley are categorised as risky (with varying degrees of risk).

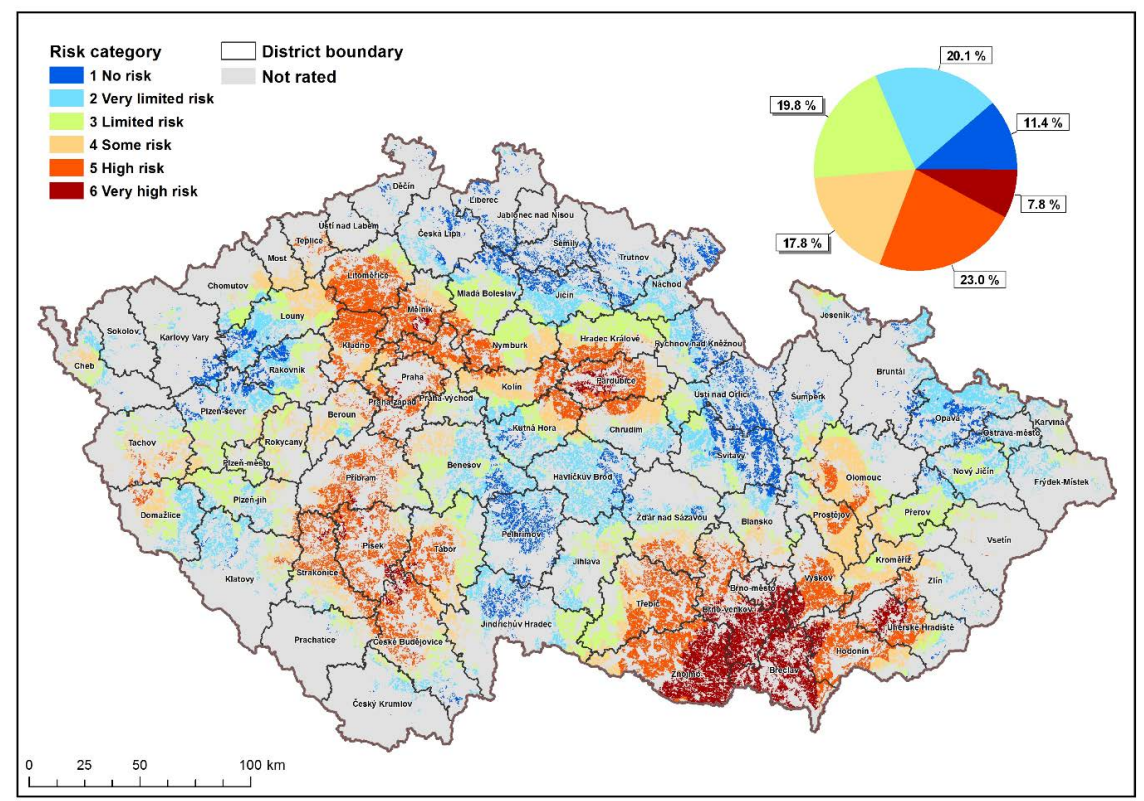

Fig. 3. The categorisation of the territory of the Czech Republic according to the risk of occurrence of abiotic stressors for spring barley.

Per the research priorities of the Ministry of Agriculture for the period 2017-2025, the map provides partial information for the optimisation of crop 
representation in each locality, organisation and optimisation of farming practices, use of minimisation and soil conservation technologies for better soil retention, utilisation of varieties tolerant to drought, and the potential for using an effective irrigation system at the time when plants need water the most.

\section{Summary}

Increasing climate variability and increasing frequency of abiotic stressors, especially drought, also result in a decrease in spring barley grain yield as well as quality by increasing the nitrogen content. In the Czech Republic, these problems are most pronounced in traditional areas of spring barley cultivation. Predictions of future climate developments suggest an increased likelihood of the occurrence of episodes unfavourable for plant production, such as dry and very warm seasons. As a short growing time and small root system, spring barley will be severely affected by these problematic episodes and is already considered a risky crop.

Drought can have various impacts on different agricultural crops, based on time of occurrence, the monitored crop and stage of its growth etc. Therefore, the methods of drought evaluation can differ greatly, and their outcomes can thus vary as well. A simple evaluation of precipitation totals is not a sufficient indicator of moisture conditions. For the exact evaluation of moisture conditions, it is advisable to use a costly direct stand microclimatic monitoring. Hence, it is necessary to use sophisticated models concerning a wide range of meteorological elements and biological characteristics of the monitored crop in order to objectively evaluate the moisture conditions in the soil-plant-atmosphere system.

The number of growing seasons with the proven effect of moisture conditions on barley yield in various production areas has increased in the last decade. These outputs demonstrate the possibility of using commonly available data sources in combination with the application of sophisticated computational methods. Their effective combination brought interesting results for the state administration, agricultural research as well as agricultural practice. The aforementioned technique is an elegant alternative to climate monitoring and costly dedicated field experiments. 
The innovative aspect of the method lies in the categorisation of the territory of the Czech Republic according to the risk of occurrence of main abiotic stressors affecting spring barley. The resulting maps also define areas that appear to be less risky on standard maps as at risk; however, depending on actual precipitation, these areas correspond to areas of spring barley with significantly reduced grain yield in recent years. The map, therefore, forms a basis for spring barley cultivation targeted for relevant features and the regionalisation of varieties.

Acknowledgements. This research was supported financially by the National Agency of Agricultural Research Ministry of Agriculture (project Nos. QK1910197 and QK1920280).

\section{References}

Blum A., 2005: Drought resistance, water-use efficiency, and yield potential — are they compatible, dissonant, or mutually exclusive? Aust. J. Agr. Res., 56, 11, 1159-1168, doi: 10.1071/AR05069.

Blum A., 2011: Plant Breeding for Water - Limited Environments. Springer - Verlag New York, $255 \mathrm{pp}$.

Bodner G., Nakhforoosh A., Kaul H.-P., 2015: Management of crop water under drought: a review. Agron. Sustain. Dev., 35, 2, 401-442, doi: 10.1007/s13593-015-0283-4.

Boyer J. S., 1982: Plant productivity and environment. Science, 218, 4571, 443-448, doi: $10.1126 /$ science.218.4571.443.

Brisson N., Gate P., Gouache D., Charmet G., Oury F.-X., Huard F., 2010: Why are wheat yields stagnating in Europe? A comprehensive data analysis for France. Field Crops Res., 119, 1, 201-212, doi: 10.1016/j.fcr.2010.07.012.

Chaves M. M., Costa J. M., Saibo N. J. M., 2011: Recent advances in photosynthesis under drought and salinity. Adv. Bot. Res., 57, 49-104, doi : 10.1016/B978-0-12 -387692-8.00003-5.

Du S., Wang Y. L., Kume T., Zhang J. G., Otsuki K., Yamanaka N., Liu G. B., 2011: Sapflow characteristics and climatic responses in three forest species in the semiarid Loess Plateau region of China. Agric. For. Meteorol., 151, 1, 1-10, doi: 10.1016/j.agrformet.2010.08.011.

Friend D. J. C., 1966: The effects of light and temperature on the growth of cereals. In: Milthorpe F. L., Ivins J. D. (Eds.): The growth of cereals and grasses. Butterworths, London, United Kingdom, pp. 181-199.

Jamieson P. D., Francis G. S., Wilson D. R., Martin R. J., 1995: Effects of water deficits on evapotranspiration from barley. Agric. For. Meteorol., 76, 1, 41-58, doi : 10.1016/0168-1923(94)02214-5. 
Kohut M., Rožnovský J., Chuchma F., 2009: The long-term soil moisture reserve variability in the Czech Republic based on the AVISO model. Sustainable Development and Bioclimate, Stará Lesná, Slovakia. Slovak Academy of Sciences: Bratislava, $160-161$.

Křen J., Klem K., Svobodová I., Míša P., Lukas V., 2015: Influence of sowing, nitrogen nutrition and weather conditions on stand structure and yield of spring barley. Cereal Res. Commun., 43, 2, 326-335, doi : 10.1556/CRC.2014.0036.

Lipiec J., Doussan, S., Nosalewicz A., Kondracka K., 2013: Effect of drought and heat stresses on plant growth and yield: a review. Int. Agrophys., 27, 4, 463-477, doi : 10.2478/intag-2013-0017.

Matejka F., Hurtalová T., Rožnovský J., Chalupníková B., 2005: Effect of soil moisture on evapotranspiration of a maize stand during one growing season. Contributions to Geophysics and Geodesy, 35, 3, 219-228.

Mužíková B., Středa T., Krmelová P., Dvořáčková O., 2013: Yields of spring barley in the climatic conditions of the Czech Republic. Kvasný Průmysl, 59, 12, 352-357, doi : $10.18832 / \mathrm{kp} 2013038$.

Naithani K. J., Ewers B. E., Pendall E., 2012: Sap flux-scaled transpiration and stomatal conductance response to soil and atmospheric drought in a semi-arid sagebrush ecosystem. J. Hydrol., 464-465, 176-185, doi : 10.1016/j.jhydrol.2012.07.008.

Rawson H. M., 1971: Tillering patterns in wheat with special reference to the shoot at the coleoptile node. Aust. J. Biol. Sci., 24, 4, 829-842, doi: 10.1071/BI9710829.

She D., Xia Y., Shao M., Peng S., Yu S., 2013: Transpiration and canopy conductance of Caragana korshinskii trees in response to soil moisture in sand land of China. Agrofor. Syst., 87, 3, 667-678, doi : 10.1007/s10457-012-9587-4.

Škvarenina J., Tomlain J., Hrvol J., Škvareninová J., Nejedlík P., 2009: Progress in dryness and wetness parameters in altitudinal vegetation stages of West Carpathians: Time-series analysis 1951-2007. Idojárás, 113, 1-2, 47-54.

Slabá V., Procházková P., Středa T., 2017: Relationship between barley yield and annual precipitation conditions. MendelNet 2017: Proceedings of International PhD Students Conference. Brno: Mendel University in Brno, 2017, 132-136.

Středová H., Středa T., 2015: Agroclimatic conditions of the Czech Republic - development and influence on agricultural production. Seed and seedlings. Prague. Czech University of Life Sciences Prague, 22-27.

Tanaka R., Nakano H., 2019: Barley yield response to nitrogen application under different weather conditions. Sci. Rep., 9, 8477, doi: 10.1038/s41598-019-44876-y.

Zeppel M. J. B., Macinnis-Ng C. M. O., Yunusa I. A. M., Whitley R. J., Eamus D., 2008: Long term trends of stand transpiration in a remnant forest during wet and dry years. J. Hydrol., 349, 1-2, 200-213, doi: 10.1016/j.jhydrol.2007.11.001. 